\title{
Burden of Disease Among Exacerbating Patients with COPD Treated with Triple Therapy in Spain
}

\author{
Bernardino Alcázar- \\ Navarrete (iD) ${ }^{1,2}$ \\ Francisco García-Rio (iD) ${ }^{2,3}$ \\ Guadalupe Sánchez (iD ${ }^{4}$ \\ Esther Mariscal ${ }^{5}$ \\ Andrea García ${ }^{5}$ \\ Maribel Cuesta ${ }^{6}$ \\ Estefany Uría ${ }^{6}$ \\ Marc Miravitlles (D) ${ }^{2,7}$ \\ 'Respiratory Department. Hospital \\ Universitario Virgen de las Nieves, \\ Granada, Spain; ${ }^{2} \mathrm{CIBER}$ de Enfermedades \\ Respiratorias (CIBERES), Madrid, Spain; \\ ${ }^{3}$ Hospital Universitario La Paz, IdiPAZ, \\ Madrid, Spain; ${ }^{4}$ Medical Department, \\ GSK, Madrid, Spain; ${ }^{5}$ Market Access \\ Department, GSK, Madrid, Spain; \\ ${ }^{6}$ Oblikue Consulting, Barcelona, Spain; \\ ${ }^{7}$ Pneumology Department, Hospital \\ Universitari Vall d'Hebron, Vall D'Hebron \\ Institut de Recerca (VHIR), Vall d'Hebron \\ Barcelona Hospital Campus, Barcelona, \\ Spain
}

Correspondence: Francisco García-Rio Hospital Universitario La Paz, Idipaz, Paseo de la Castellana, 26I, Madrid, 28046, Spain

Tel +34917277000

Email fgr0Im@gmail.com
Background: The cost of chronic obstructive pulmonary disease (COPD) in Spain has been studied from different perspectives, but parameters such as the patient's phenotype have seldom been considered. Our aim was to describe the disease burden of COPD patients with frequent exacerbator phenotype, treated with triple therapy.

Methods: An observational, multicenter study was carried out from December 2017 to November 2018 in pulmonology services among patients $\geq 40$ years with COPD confirmed diagnosis receiving triple therapy (ICS/LAMA/LABA) and history of $\geq 2$ moderate or $\geq 1$ severe exacerbation in the 12 months prior to the inclusion visit. COPD-related healthcare resources were collected over a 12-months period prior to the inclusion visit: pharmacological and non-pharmacological treatments, medical and ER visits, hospitalizations, tests and productivity loss. Costs were updated to $€ 2019$. Patients were classified according to blood eosinophil levels: $<150$ cells $/ \mu \mathrm{L}$ and $\geq 150$ cells $/ \mu \mathrm{L}$.

Results: A total of 306 patients were included (77.1\% men), with mean age of 69.9 years. Mean COPD exacerbation rate was $2.5 /$ patient/year and $51.3 \%$ of patients had $\geq 150$ cells $/ \mu \mathrm{L}$ eosinophil level. On average, for the total population, COPD-related visits/patients/year were 6.2. Resource use in moderate exacerbation was higher in patients with eosinophils $\geq 150$ cells $/ \mu \mathrm{L}$, whereas in severe exacerbation was higher in patients with eosinophils $<150$ cells/ $\mu \mathrm{L}$. According to eosinophil levels, total annual mean (SD) costs/patient accounted for $€ 8382$ (9863) and $€ 5144$ (5444) for patients with eosinophils $<150$ cells $/ \mu \mathrm{L}$ and $\geq 150$ cells $/ \mu \mathrm{L}$, respectively.

Conclusion: The impact of exacerbating COPD patients treated with triple therapy in Spain is large, especially among those with eosinophils $<150$ cells $/ \mu \mathrm{L}$.

Keywords: frequent exacerbation, triple therapy, cost, eosinophil, health care resources, COPD

\section{Introduction}

Chronic obstructive pulmonary disease (COPD) remains a major health problem in Spain and worldwide. The prevalence keeps growing and is expected to be the third leading cause of death in $2020 .{ }^{1}$ The results of the EPI-SCAN II study ${ }^{2}$ indicates that $11.8 \%$ of the Spanish population aged $>40$ years has COPD.

COPD entails a high economic burden associated with a consumption of health resources and a loss of health-related quality of life. ${ }^{3-6}$ COPD exacerbations make up a large part of this economic burden and have also a significant impact on patients and their environment. In addition, they are associated with a higher likelihood of future exacerbations, more rapid functional impairment and increased mortality. $^{7,8}$ 
Therefore, identification of biomarkers for the diagnosis and prognosis of COPD could help establishing more accurate therapeutic strategies and improving health outcomes. Blood eosinophils count have been suggested as a useful biomarker for response to therapy in COPD. Studies show that COPD patients with elevated eosinophil levels ( $\geq 150$ cells $/ \mu \mathrm{L}$ ) have a greater reduction in the rate of exacerbations when treated with inhaled corticosteroids (ICS). ${ }^{9,10}$ Some studies suggest that blood eosinophil levels could also be used to direct systemic corticosteroid therapy during exacerbations. ${ }^{11,12}$ Moreover, it has been noted that blood eosinophil levels in COPD patients might be considered as a possible prognostic biomarker. ${ }^{13}$ However, the use of blood eosinophil counts as a predictor of the risk of exacerbations is less clear, and some studies suggest that it is not useful in populations at low risk of exacerbations. ${ }^{14,15}$

In Spain, the cost of COPD has been studied from different perspectives, ${ }^{4,5,16,17}$ but parameters such as the patient phenotype have not been taken into account. To remedy this lack of information, this observational study was designed to more specifically describe the disease burden and health resource use of patients with exacerbating COPD treated with triple therapy and a different eosinophilic profile.

\section{Methods}

\section{Study Design}

An epidemiological, observational, retrospective, multicenter study was carried out in pulmonology services from 20 Spanish hospitals to estimate the burden of exacerbating COPD in Spain. Patients with COPD who attended a follow-up visit and met all selection criteria were consecutively invited to participate in the study until the required number of patients was fulfilled. Only one visit per patient was required and no follow-up visits were made. The study was approved by the Clinical Research and Ethics Committee of Hospital Universitari Vall d'Hebron (Barcelona, Spain) and all patients provided signed informed consent to participate in the study. It was carried out in accordance with the principles of Declaration of Helsinki and complied with the standards of Good Clinical Practice ${ }^{18}$ as well as following the guidelines for Good Epidemiological Practice. ${ }^{19}$

The study did not impede normal diagnostic or therapeutic action in usual clinical practice, which are based on national/international recommendations and guidelines.
The economic assessment was carried out from the social perspective. The study period was December 2017 to November 2018. The time horizon of the analysis was 12 months before the inclusion visit.

\section{Study Population}

Patients with the following criteria were included: (1) age $\geq 40$ years; (2) previous COPD diagnosis with a postbronchodilator $\mathrm{FEV}_{1} / \mathrm{FVC}<70 \%$ recorded at any time in the medical record; (3) current or past smoking with a cumulative exposure $\geq 10$ pack-years; (4) blood eosinophil test recorded in the 3 months before the inclusion visit; (5) treatment with triple inhaled maintenance therapy at inclusion (ICS/ long-acting beta-2 agonist (LABA)/ long-acting muscarinic antagonist (LAMA)) without more than 30 days of separation between prescriptions; (6) $\geq 2$ moderate or $\geq 1$ severe exacerbations in the 12 months before the inclusion visit; and (7) signed the patient's written informed consent form. Exclusion criteria were: (1) patients without a qualifying peripheral blood eosinophil count recorded in the 3 months prior to the inclusion visit and who refuse to perform the test during the inclusion visit; (2) patients treated with oral corticosteroids on an ongoing basis during the 12 months before the inclusion visit; (3) diagnosis of eosinophilic granulomatosis with polyangiitis, hypereosinophilic syndrome, allergic bronchopulmonary aspergillosis or other conditions resulting in increased eosinophil levels independent of COPD; (4) patients with oncological disease under treatment or in advanced stages with no possibility of remission, terminal states and/or receiving palliative care; (5) cognitively impaired patients; and (6) participation in an interventional clinical trial during the 12 months prior.

Patients were stratified into two groups according to blood eosinophil levels: $<150$ cells $/ \mu \mathrm{L}$ and $\geq 150$ cells $/ \mu \mathrm{L}$.

\section{Data Collection}

Sociodemographic characteristics and clinical variables such as body mass index (BMI), smoking history, concomitant diseases and COPD characteristics such as time from COPD diagnosis, modified dyspnoea scale $(\mathrm{mMRC}),{ }^{20}$ spirometry and blood biochemical data were collected.

\section{Main Outcomes}

Moderate exacerbation was defined as an acute increase in respiratory symptoms requiring a prescription for antibiotics and/or oral corticosteroids or an emergency visit $<24$ 
hours, while a severe exacerbation was defined as that requiring hospitalization or emergency visit for $\geq 24$ hours.

Resource use in the stable phase, including primary care (PC) and secondary care (SC) medical visits, outpatient tests, pharmacological and non-pharmacological treatments, and related to the moderate and/or severe exacerbations (hospitalizations, pharmacologic treatments, emergency visits, PC and SC visits) were collected. The days of lost work attributable to COPD, the impact of COPD on patients measured by the COPD Assessment Test (CAT) questionnaire ${ }^{21}$ and health-related quality of life (HRQoL) using the Spanish version of the selfadministered EuroQoL 5 Dimensions (EQ-5D-5L) ${ }^{22}$ were also collected. Utilities were calculated based on the results of the EQ-5D-5L questionnaire. The health states were converted into a weighted index score that ranges from 0 to 1 , with 0 being the reference value assigned to death and 1 being perfect health. Spanish weighting for each dimension was applied according to the individual responses, resulting in the tariff applied. ${ }^{23}$

For pharmacological treatments, the total dose was calculated for each of the active substances during the last 12 months in the stable phase and for the duration of the exacerbations. The dose was multiplied by the time on treatment. In cases where the dosing schedule was on demand, the minimum dose according to the data sheet was assigned.

\section{Costs}

To estimate the economic impact from the social perspective, direct health care costs due to resource use in the stable phase and to moderate and severe COPD exacerbations; and indirect costs due to working days lost, were included.

The unit costs of resource use were obtained from ESALUD, (database of reported Spanish healthcare costs) ${ }^{24}$ (Supplementary Table A-1) and the costs of pharmacological treatments were obtained from the website of the General Council of Official Colleges of Pharmacists ${ }^{25}$ plus value added tax without applying the deduction of Royal Decree-Law 8/2010. ${ }^{26}$ Working days lost were measured using the latest data published by the National Statistical Institute in the 2016 survey of the salary structure $^{27}$ (Supplementary Table A-1). All costs were expressed in 2019 euros.

\section{Direct Healthcare Costs}

Direct healthcare costs included resource use in the stable phase: medical visits, outpatient tests, pharmacological and non-pharmacological treatments; and resource use due to exacerbations: hospitalizations, intensive care unit (ICU), emergency/PC/SC visits and pharmacological treatment. The costs of emergency, PC and SC visits, outpatient tests and non-pharmacological treatments were calculated by multiplying the natural units of the resources used by the unit cost. The cost of hospitalizations was obtained by multiplying the days of stay by the corresponding unit cost.

The costs of each pharmacological treatment were obtained by multiplying the total dose each patient received during the stable phase and during exacerbations by the unit cost of each treatment.

\section{Indirect Costs}

The costs of lost working days attributable to COPD were included as indirect costs. The calculation was made according to the human capital method, considering that the salary reflects the worker's productivity. Therefore, the days that the patient was unable to work due to COPD were multiplied by the most up-to-date salary cost.

\section{Statistical Analysis}

A descriptive analysis of the study variables was made. Quantitative variables were described using means and standard deviation (SD) or, in the case of time from diagnosis, median and interquartile range (IQR). Qualitative variables were analysed at absolute and relative frequencies. For comparisons between patients with eosinophils $<150$ cells $/ \mu \mathrm{L}$ and $\geq 150$ cells $/ \mu \mathrm{L}$, the Mann Whitney $U$-test was used for continuous variables and the exact Fisher test and the $\chi^{2}$ test for categorical variables, depending on the nature of the comparative variable. The analysis was made using the $\mathrm{R}$ statistical package (version 3.5.1).

\section{Sample Size}

To obtain a representative sample of patients with severe exacerbating COPD treated with triple therapy, the necessary number of patients was calculated according to the estimated prevalence of Spanish patients with severe COPD $(5.2 \%$ according to the EPI-SCAN study) ${ }^{28}$ and the mean proportion of these with eosinophils $\geq 150$ cells $/ \mu \mathrm{L}$ (estimated at between $40 \%$ and $60 \%)^{29,30}$ Given this data and a $95 \%$ confidence interval, a $2 \%$ precision, and a reposition percentage of $10 \%$, an estimate of 250 patients with $\geq 150$ cells $/ \mu \mathrm{L}$ was needed. Similarly, the adequate number of patients with $<150$ cell $/ \mu \mathrm{L}$ needed to evaluate secondary objectives was 104 , considering 
the prevalence of patients with severe COPD in Spain already cited and an estimated proportion of patients with these eosinophil values of approximately $40 \%$. Thus, the number of patients considered necessary was 354 .

\section{Results}

The initial cohort included 341 patients with exacerbating COPD treated with triple therapy, of whom 306 were valid for the analysis and $51.3 \%$ of them had blood eosinophil levels of $\geq 150$ cells $/ \mu \mathrm{L}$. Reasons for exclusion are described in Figure 1.

Of the 306 patients, $77.1 \%$ were male and the mean age (SD) was 69.9 (9.2) years. Former smokers accounted for $79.4 \%$ of patients, with a mean number (SD) of pack-year of 54.8 (31.7). Similar results were observed in sociodemographic and clinical characteristics by stratifying patients according to eosinophil levels. The mean (SD) postbronchodilator $\mathrm{FEV}_{1}$ was $44.5 \%$ (16.4) for the total population and $42.7 \%$ (15.6) and $46.3 \%$ (17.0) for patients with eosinophils $<150$ cells $/ \mu \mathrm{L}$ and $\geq 150$ cells $/ \mu \mathrm{L}$, respectively (Table 1). In $68.5 \%$ of patients, eosinophil levels were collected in the stable phase $(53.0 \%$ and $83.3 \%$ in patients with eosinophils $<150$ cells $/ \mu \mathrm{L}$ and $\geq 150$ cells $/ \mu \mathrm{L}$, respectively).

For the total population, 21 patients had $\geq 1$ sick leave in the last 12 months (mean (SD):8.6 (51.2) days/patient). According to eosinophil levels, $8.1 \%$ and $5.7 \%$ of patients with eosinophils $<150$ cells $/ \mu \mathrm{L}$ and $\geq 150$ cells $/ \mu \mathrm{L}$, respectively had $\geq 1$ sick leave in the last 12 months. The mean (SD) working days lost due to COPD in this period was 14.3 (66.5) and 3.2 (29.5) days/patient, in patients with eosinophils $<150$ cells $/ \mu \mathrm{L}$ and $\geq 150$ cells $/ \mu \mathrm{L}$, respectively. No significant differences in working days lost according to eosinophil levels were observed.

According to the CAT questionnaire results, COPD had a high $(27.0 \%)$ or very high impact $(9.2 \%)$ on symptoms. In the EQ-5D-5L questionnaire, the mean utilities score (SD) was $0.6(0.3)$ for the total population. No significant differences between the two groups of patients were observed either in CAT or in EQ-5D-5L scores (Table 1).

\section{Resource Use}

Two hundred and five of the 306 patients included, had $\geq 1$ moderate exacerbation and 194 had $\geq 1$ severe exacerbation. The mean number (SD) of exacerbations (moderate and/or severe) was 2.5 (1.4) (Table 1).

Of patients with eosinophils $<150$ cells $/ \mu \mathrm{L}, 59.1 \%$ had $\geq 1$ moderate exacerbation (mean [SD]: 1.2 [1.4] exacerbations/patient), while $75.8 \%$ had $\geq 1$ severe exacerbation (mean [SD]: 1.3 [1.2] exacerbations/patient). Of patients with eosinophils $\geq 150$ cells $/ \mu \mathrm{L}, 74.5 \%$ had $\geq 1$ moderate exacerbation (mean (SD): 1.7 (1.5) exacerbations/patient),

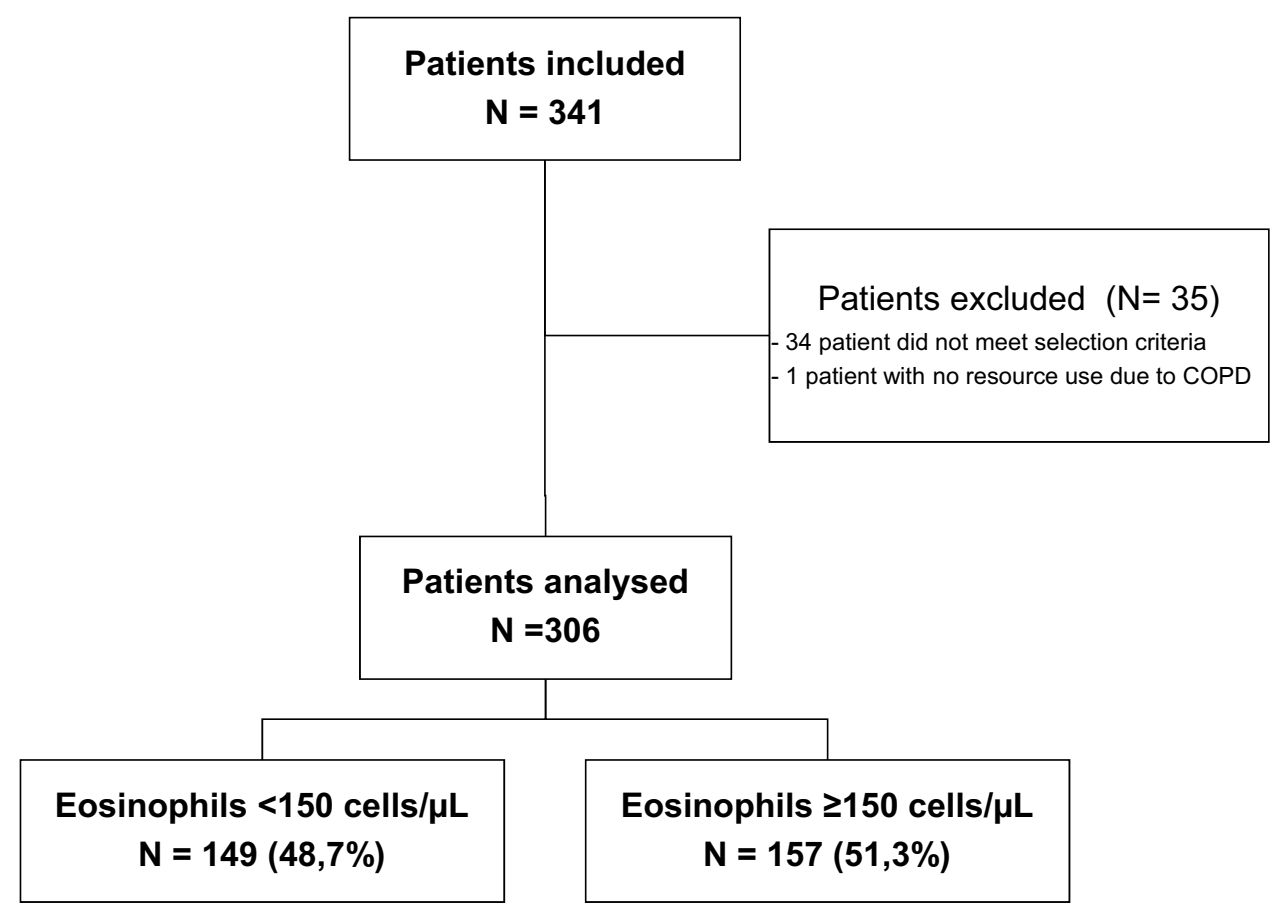

Figure I Patient flow according to STROBE guide.

Abbreviation: COPD, chronic obstructive pulmonary disease. 
Table I Sociodemographic and Clinical Variables of COPD and Impact on the Quality of Life of Patients with Exacerbating COPD Treated with Triple Therapy

\begin{tabular}{|c|c|c|c|c|}
\hline Variables & $\begin{array}{l}\text { Total Sample } \\
\mathrm{N}=306(100.0 \%)\end{array}$ & $\begin{array}{c}\text { Eosinophils }<150 \text { Cells/ } / \mathrm{L} \\
\mathrm{N}=149(48.7 \%)\end{array}$ & $\begin{array}{c}\text { Eosinophils } \geq 150 \text { Cells } / \mu \mathrm{L} \\
\mathrm{N}=157(51.3 \%)\end{array}$ & P-value ${ }^{a}$ \\
\hline \multicolumn{5}{|l|}{ Sociodemographic variables } \\
\hline \multicolumn{5}{|l|}{ Age (years) } \\
\hline Mean (SD) & $69.9(9.2)$ & $70.5(9.0)$ & $69.3(9.4)$ & 0.310 \\
\hline \multicolumn{5}{|l|}{ Sex - n (\%) } \\
\hline Male & $236(77.1 \%)$ & 114 (76.5\%) & 122 (77.7\%) & 0.910 \\
\hline \multicolumn{5}{|l|}{ Clinical features } \\
\hline \multicolumn{5}{|l|}{ BMI $\left(\mathrm{kg} / \mathrm{m}^{2}\right)$} \\
\hline Mean (SD) & $27.5(5.5)$ & $27.4(5.9)$ & $27.6(5.0)$ & 0.465 \\
\hline \multicolumn{5}{|l|}{ Smoking - n (\%) } \\
\hline Former smoker ${ }^{b}$ & $243(79.4 \%)$ & 115 (77.2\%) & $128(81.5 \%)$ & 0.424 \\
\hline Current smoker & $63(20.6 \%)$ & $34(22.8 \%)$ & $29(18.5 \%)$ & \\
\hline \multicolumn{5}{|l|}{ Number of packs-year } \\
\hline Mean (SD) & $54.8(31.7)$ & $54.6(32.1)$ & $55.0(31.3)$ & 0.936 \\
\hline \multicolumn{5}{|l|}{ Comorbidities - n (\%) } \\
\hline Diabetes without target organ involvement & $51(16.7 \%)$ & $20(13.4 \%)$ & $31(19.7 \%)$ & 0.184 \\
\hline Congestive heart failure & $4 \mathrm{I}(13.4 \%)$ & $21(14.1 \%)$ & $20(12.7 \%)$ & 0.857 \\
\hline Myocardial infarction & $39(12.7 \%)$ & $18(12.1 \%)$ & $21(13.4 \%)$ & 0.866 \\
\hline Malignancies & $28(9.1 \%)$ & $15(10.1 \%)$ & $13(8.3 \%)$ & 0.731 \\
\hline Kidney disease & $27(8.8 \%)$ & $8(5.4 \%)$ & $19(12.1 \%)$ & 0.061 \\
\hline Peripheral vascular disease & $23(7.5 \%)$ & $10(6.7 \%)$ & $13(8.3 \%)$ & 0.762 \\
\hline Other ${ }^{c}$ & $74(24.2 \%)$ & $4 \mathrm{I}(27.5 \%)$ & $33(21.0 \%)$ & 0.185 \\
\hline \multicolumn{5}{|l|}{ COPD features } \\
\hline \multicolumn{5}{|l|}{ Time from diagnosis (years) $^{d}$} \\
\hline Median (IQR) & $8.0[5.0-12.0]$ & $8.0[5.0-13.0]$ & $8.0[5.0-11.0]$ & 0.565 \\
\hline \multicolumn{5}{|l|}{ Modified dyspnoea scale score (mMRC) - n (\%) } \\
\hline Grade 0 & $8(2.6 \%)$ & $2(1.3 \%)$ & $6(3.8 \%)$ & 0.036 \\
\hline Grade I & $61(19.9 \%)$ & $21(14.1 \%)$ & $40(25.5 \%)$ & \\
\hline Grade 2 & $124(40.5 \%)$ & $65(43.6 \%)$ & $59(37.6 \%)$ & \\
\hline Grade 3 & $85(27.8 \%)$ & 43 (28.9\%) & $42(26.7 \%)$ & \\
\hline Grade 4 & $28(9.2 \%)$ & $18(12.1 \%)$ & $10(6.4 \%)$ & \\
\hline \multicolumn{5}{|l|}{ Post-bronchodilator $\mathrm{FEV}_{1}(\%$ predicted $)$} \\
\hline Mean (SD) & $44.5(16.4)$ & $42.7(15.6)$ & $46.3(17.0)$ & 0.098 \\
\hline \multicolumn{5}{|l|}{ Post-bronchodilator $\mathrm{FEV}_{\mathrm{I}} / \mathrm{FVC}$ (\%) } \\
\hline Mean (SD) & $46.9(12.1)$ & $45.6(11.2)$ & $48.2(12.9)$ & 0.055 \\
\hline \multicolumn{5}{|l|}{ Eosinophils (cells/ $\mu \mathrm{L}$ ) } \\
\hline Mean (SD) & $217.9(384.9)$ & $61.3(51.5)$ & 366.6 (491.4) & $<0.001$ \\
\hline \multicolumn{5}{|l|}{ Impact of COPD on quality of life } \\
\hline \multicolumn{5}{|l|}{ Total CAT score } \\
\hline Mean (SD) & $17.4(8.5)$ & $17.7(8.3)$ & $17.1(8.7)$ & 0.512 \\
\hline
\end{tabular}


Table I (Continued).

\begin{tabular}{|c|c|c|c|c|}
\hline Variables & $\begin{array}{l}\text { Total Sample } \\
\mathrm{N}=306(100.0 \%)\end{array}$ & $\begin{array}{c}\text { Eosinophils }<150 \text { Cells/ } \mu \mathrm{L} \\
\mathrm{N}=149(48.7 \%)\end{array}$ & 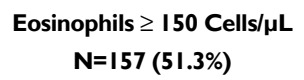 & P-value ${ }^{a}$ \\
\hline Low impact (CAT score $\leq 10)-\mathrm{n}(\%)$ & $73(24.0 \%)$ & $30(20.3 \%)$ & $43(27.6 \%)$ & \multirow[t]{4}{*}{0.328} \\
\hline Moderate impact (CAT score $>10$ and $\leq 20)-n(\%)$ & 121 (39.8\%) & $66(44.6 \%)$ & $55(35.3 \%)$ & \\
\hline High impact (CAT score $>20$ and $\leq 30)-\mathrm{n}(\%)$ & $82(27.0 \%)$ & 39 (26.3\%) & $43(27.6 \%)$ & \\
\hline Very high impact (CAT score $\geq 30)-n(\%)$ & $28(9.2 \%)$ & $13(8.8 \%)$ & $15(9.6 \%)$ & \\
\hline \multicolumn{5}{|l|}{ Utilities (EQ-5D-5L) } \\
\hline Mean (SD) & $0.6(0.3)$ & $0.6(0.3)$ & $0.7(0.3)$ & 0.270 \\
\hline \multicolumn{5}{|l|}{ Number of exacerbations (patient/year) } \\
\hline \multicolumn{5}{|l|}{ Total exacerbations } \\
\hline Mean (SD) & $2.5(1.4)$ & $2.5(1.6)$ & $2.5(1.3)$ & 0.421 \\
\hline \multicolumn{5}{|l|}{ Moderate exacerbations } \\
\hline Mean (SD) & $1.5(1.4)$ & $1.2(1.4)$ & $1.7(1.5)$ & 0.001 \\
\hline \multicolumn{5}{|l|}{ Severe exacerbations } \\
\hline Mean (SD) & $1.0(1.1)$ & $1.3(1.2)$ & $0.8(0.9)$ & $<0.001$ \\
\hline
\end{tabular}

Notes: ${ }^{a}$ P-value between patients with eosinophils $<150$ cells $/ \mu \mathrm{L} v \mathrm{vs} \geq 150$ cells/ $\mathrm{LL}$. The chi-square test was used for dichotomous variables and the Mann-Whitney $U$-test for quantitative variables. ${ }^{b}$ Ex-smoker: Former smoker who has not smoked for at least the last 6 months. ${ }^{c}$ Others in the global population: Peptic ulcer (n-I6), rheumatological disease (n-15), mild liver disease $(n-14)$, cerebrovascular disease $(n-10)$, diabetes with target organ involvement (n-7), acquired immunodeficiency syndrome $(n-4)$, moderate or severe liver disease $(n-3)$, hemiplegia or paraplegia $(n-3)$, dementia $(n-I)$, metastasis of solid tumours ( $n-1)$. ${ }^{d}$ Until the inclusion visit.

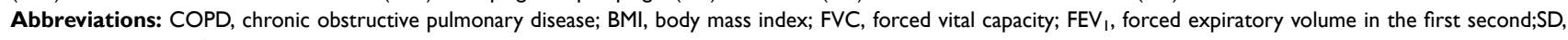
standard deviation; IQR, interquartile range.

while $51.6 \%$ had $\geq 1$ severe exacerbation (mean (SD): 0.8 (0.9) exacerbations/patient) (Table 1).

Figure 2 shows resource use due to moderate and severe exacerbations. The mean hospital stay (SD) was 11.6 (10.9) days for the total study population and 13.1 (12.7) and 9.5 (7.3) days for patients with eosinophils $<150$ cells $/ \mu \mathrm{L}$ and $\geq 150$ cells $/ \mu \mathrm{L}$, respectively. No significant differences in the number of visits, the number of hospital admissions or the mean hospital length of stay were observed according to eosinophil levels.

Table 2 shows the use of resources during stable phase. Significant differences were only observed in number of PC visits, blood analysis and bronchodilators tests, which were more frequent in patients with $\geq 150$ eosinophils $/ \mu \mathrm{L}$ (Table 2).

\section{Costs}

Table 3 and Figure 3 show the costs due to COPD during the last 12 months for the total population and according to blood eosinophil levels. For the total population, the annual mean cost (SD) per patient was €155.8 (€240.9) for moderate and $€ 3117.9$ ( $€ 4372.5$ ) for severe exacerbations. Annual mean cost (SD) per patient during the stable phase was $€ 2427.5$ ( $€ 1377.3$ ) (Table 3). Pharmacological treatments accounted for more than $40 \%$ of the cost in the stable phase (Figure 3). Annual indirect mean cost (SD) per patient due to COPD was $€ 1019.5$ (€6066.1) (Table 3).

The total annual mean direct health costs (SD) per patient was $€ 5701.3$ ( $€ 4733.0$ ). Adding indirect costs gave a total mean cost (SD) of €6720.7 (€8061.3). According to eosinophil levels, the total annual mean cost (SD) was €8381.7 (€9862.5) and €5144.4 (€5443.9) for patients with eosinophils $<150$ cells $/ \mu \mathrm{L}$ and $\geq 150$ cells/ $\mu \mathrm{L}$, respectively (Table 3 ).

\section{Discussion}

This study assessed the impact of exacerbating COPD patients treated with triple therapy in Spain through the analysis of direct and indirect costs and their quality of life, providing information about the economic burden of the disease and patients' self-perception of their health status. These patients with a phenotype of frequent and/ or severe exacerbations have a higher risk of hospitalization and an increased risk of death. ${ }^{31}$

The annual cost of a patient with exacerbating COPD treated with triple therapy in Spain from the social 


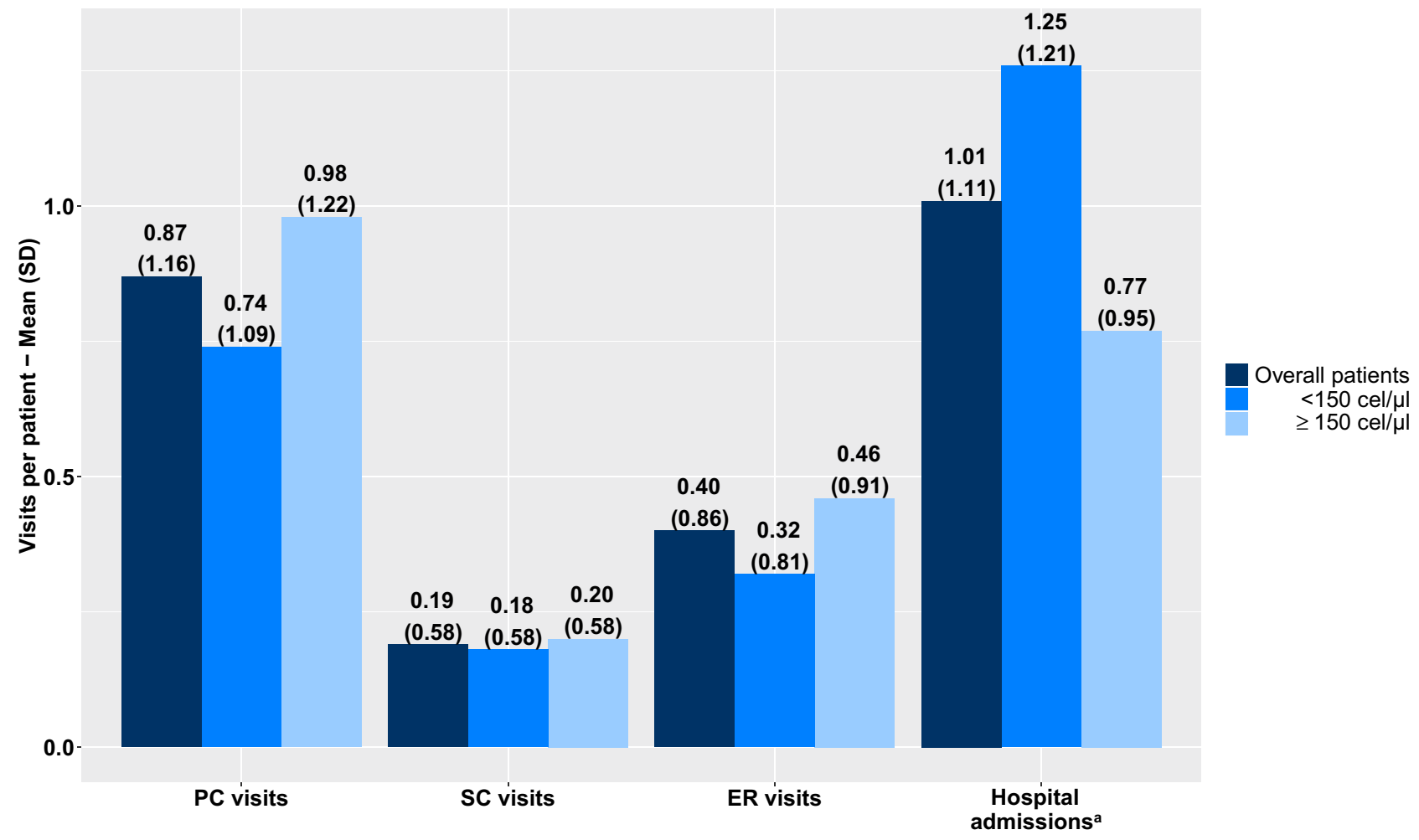

Figure 2 Use of resources for COPD exacerbations (per patient) in patients with exacerbating COPD treated with triple therapy: total population and according to blood eosinophil levels $(<150$ cells $/ \mu \mathrm{L}, \geq 150$ cells $/ \mu \mathrm{L})$.

Notes: ${ }^{a}$ Statistical difference in hospital admission according to blood eosinophil levels $(<150$ cells $/ \mu \mathrm{L}, \geq 150 \mathrm{cells} / \mu \mathrm{L})$.

Abbreviations: COPD, chronic obstructive pulmonary disease; PC, primary care; SC, secondary care, ER, emergency room; SD, standard deviation.

perspective was $€ 6721$ (84.8\% direct costs and $15.2 \%$ indirect costs). To the best of our knowledge, this is the first Spanish multicenter study of costs in patients with exacerbating COPD who receive the maximum possible inhaled treatment; therefore, we cannot compare our data with similar studies. However, our results can be compared with cost analysis developed using different designs or performed in different populations. In this regard, the costs obtained in our study were higher than those reported in other Spanish studies, which showed an annual direct cost of COPD between $€ 890$ and $€ 3085$ per patient. ${ }^{3,4,17,32}$ The 2018 study by Merino et al, ${ }^{4}$ estimated the annual cost of COPD at $€ 3757 /$ patient (82.1\% direct costs and $17.9 \%$ indirect costs). The total costs in our study were almost twice as high. In addition to the subtle differences in resource use accounting, the main reason for the higher cost is probably that our study only included patients with exacerbating COPD.

According to the eosinophil level, the mean annual cost was $€ 8382$ and $€ 5144$ for patients with eosinophils $<150$ cells $/ \mu \mathrm{L}$ and $\geq 150$ cells $/ \mu \mathrm{L}$, respectively. Although the total number of exacerbations was not significantly different between both groups of patients, those with low eosinophils had a higher frequency of hospital admissions, which accounted for the significantly increased costs compared with patients with high eosinophils. The relationship between blood eosinophil counts and frequency of exacerbations remains controversial. Some studies have found a significant increase in severe exacerbations in patients with higher eosinophils, ${ }^{13,33}$ while others have not found any relationship in populations of patients at low risk of exacerbations. ${ }^{14,15}$ In general, our results support the lack of association of blood eosinophil counts and frequency of exacerbations, at least in patients receiving triple therapy.

The benefits of triple therapy have been extensively studied, and there is a greater effect on lung function and a decrease in exacerbations and hospitalizations in severe patients compared to other alternatives of treatment, in particular in patients with high blood eosinophil counts. ${ }^{34}$ However, some high-risk patients may still not have good disease control despite receiving triple therapy, as seen in the results of this and previous studies. ${ }^{35-37}$ All this reflects that there are still unmet needs in treatment of patients with COPD. 
Table 2 Use of Resources Due to Stable-Phase COPD (per Patient) in Patients with Exacerbating COPD Treated with Triple Therapy

\begin{tabular}{|c|c|c|c|c|}
\hline Variables & $\begin{array}{c}\text { Total Sample } \\
N=306(100.0 \%)\end{array}$ & $\begin{array}{c}\text { Eosinophils }<150 \text { Cells/ } \mu \mathrm{L} \\
\mathrm{N}=149(48.7 \%)\end{array}$ & 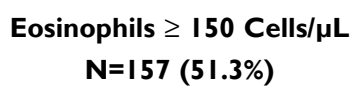 & P-value ${ }^{a}$ \\
\hline \multicolumn{5}{|l|}{ Visits } \\
\hline $\begin{array}{l}\text { Number of total visits } \\
\text { Mean (SD) }\end{array}$ & $6.2(4.2)$ & $5.8(3.8)$ & $6.6(4.5)$ & 0.125 \\
\hline $\begin{array}{l}\text { Number of PHC physician visits } \\
\text { Mean (SD) }\end{array}$ & $3.7(3.8)$ & $3.3(3.5)$ & $4.1(3.9)$ & 0.037 \\
\hline $\begin{array}{l}\text { Number of specialized medical visits } \\
\text { Mean (SD) }\end{array}$ & $2.5(1.7)$ & $2.5(1.5)$ & $2.5(1.9)$ & 0.492 \\
\hline \multicolumn{5}{|l|}{ Outpatient tests ${ }^{c}$} \\
\hline $\begin{array}{l}\text { Spirometries } \\
\text { Mean (SD) }\end{array}$ & I.3 (0.7) & I.3 (0.7) & I.4 (0.8) & 0.348 \\
\hline $\begin{array}{l}\text { Blood analyses } \\
\text { Mean (SD) }\end{array}$ & $2.8(3.8)$ & $2.6(3.4)$ & $3.1(4.2)$ & 0.030 \\
\hline $\begin{array}{l}\text { Chest X-rays } \\
\text { Mean (SD) }\end{array}$ & $1.5(1.8)$ & I.4 (I.5) & $1.6(2.1)$ & 0.809 \\
\hline $\begin{array}{l}\text { Bronchodilator tests } \\
\text { Mean (SD) }\end{array}$ & $0.8(0.8)$ & $0.7(0.7)$ & $0.9(0.8)$ & 0.035 \\
\hline $\begin{array}{l}\text { Arterial blood gases } \\
\text { Mean (SD) }\end{array}$ & $1.0(1.6)$ & $1.0(1.7)$ & $0.9(1.5)$ & 0.188 \\
\hline $\begin{array}{l}\text { Lung volumes and/or DLCO } \\
\text { Mean (SD) }\end{array}$ & $0.02(0.1)$ & $0.03(0.2)$ & $0.0 \mathrm{I}(0.1)$ & 0.374 \\
\hline $\begin{array}{l}\text { 6-minute walk test } \\
\text { Mean (SD) }\end{array}$ & $0.3(0.5)$ & $0.2(0.4)$ & $0.3(0.5)$ & 0.535 \\
\hline $\begin{array}{l}\text { Chest CT } \\
\text { Mean (SD) }\end{array}$ & $0.2(0.5)$ & $0.3(0.5)$ & $0.2(0.5)$ & 0.875 \\
\hline $\begin{array}{l}\mathrm{FE}_{\mathrm{NO}} \text { measurements } \\
\text { Mean (SD) }\end{array}$ & $0.1(0.4)$ & $0.1(0.4)$ & $0.2(0.5)$ & 0.531 \\
\hline Non-pharmacological treatment & & & & \\
\hline Influenza vaccination - n (\%) & 249 (8I.4\%) & 119 (79.9\%) & $130(82.8 \%)$ & 0.608 \\
\hline Pneumococcal vaccination - $\mathrm{n}(\%)$ & 197 (64.4\%) & $94(63.1 \%)$ & $103(65.6 \%)$ & 0.734 \\
\hline Home oxygen - n (\%) & $102(33.3 \%)$ & $55(36.9 \%)$ & 47 (29.9\%) & 0.241 \\
\hline Respiratory rehabilitation - n (\%) & $22(7.2 \%)$ & $12(8.0 \%)$ & $10(6.4 \%)$ & 0.727 \\
\hline Non-invasive home ventilation - $\mathrm{n}(\%)$ & $20(6.5 \%)$ & $13(8.7 \%)$ & 7 (4.5\%) & 0.201 \\
\hline Drug treatment ${ }^{\mathrm{d}, \mathrm{e}}$ & & & & \\
\hline LAMA - n (\%) & $217(70.9 \%)$ & $108(72.5 \%)$ & 109 (69.4\%) & 0.556 \\
\hline LABA/ICS - n (\%) & $214(69.9 \%)$ & $108(72.5 \%)$ & $106(67.5 \%)$ & 0.344 \\
\hline SABA - n (\%) & $122(39.9 \%)$ & $58(38.9 \%)$ & $64(40.8 \%)$ & 0.743 \\
\hline ICS - n (\%) & $94(30.7 \%)$ & $43(28.9 \%)$ & 51 (32.5\%) & 0.492 \\
\hline
\end{tabular}


Table 2 (Continued).

\begin{tabular}{|c|c|c|c|c|}
\hline Variables & $\begin{array}{c}\text { Total Sample } \\
\text { N=306 (100.0\%) }\end{array}$ & 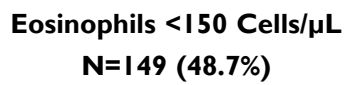 & $\begin{array}{c}\text { Eosinophils } \geq 150 \text { Cells/ } \mu \mathrm{L} \\
\mathrm{N}=157(51.3 \%)\end{array}$ & P-value ${ }^{a}$ \\
\hline LABA/LAMA - n (\%) & $92(30.1 \%)$ & $42(28.2 \%)$ & $50(31.8 \%)$ & 0.485 \\
\hline Other airway agents $-\mathrm{n}(\%)$ & $43(14.0 \%)$ & $21(14.1 \%)$ & $22(\mid 4.0 \%)$ & 0.984 \\
\hline
\end{tabular}

Notes: ${ }^{\mathrm{a}} \mathrm{P}$-value between patients with eosinophils $<150$ cells $/ \mu \mathrm{L}$ vs $\geq 150$ cells $/ \mu \mathrm{L}$. The chi-square test was used for dichotomous variables and the Mann-Whitney $\mathrm{U}$-test for quantitative variables. ${ }^{b}$ Not including inclusion visit. ${ }^{~}$ Outpatient tests required by $<5 \%$ of patients not shown. ${ }^{\mathrm{d}}$ Treatment prescribed in $<10 \%$ of patients not shown. ${ }^{\mathrm{e}} \mathrm{Categories}$ mutually non-exclusive.

Abbreviations: COPD, chronic obstructive pulmonary disease; PHC, primary healthcare; DLCO, lung diffusion capacity; CT, computed tomography; $F_{N O}$, exhaled nitric oxide; $S A B A$, short-acting inhaled adrenergic; LABA, long-acting $\beta$ agonists; LAMA, long-acting muscarinic antagonist; ICS, inhaled corticosteroids; SD, standard deviation; IQR, interquartile range.

Table 3 Total Costs per Patient Due to COPD During the Last 12 Months in Patients with Exacerbating COPD Treated with Triple Therapy ${ }^{\mathrm{a}}$

\begin{tabular}{|c|c|c|c|c|}
\hline Variables & $\begin{array}{l}\text { Total Sample } \\
N=306 \\
(100.0 \%)\end{array}$ & $\begin{array}{l}\text { Eosinophils <I50 } \\
\text { Cells/ } \mu \mathrm{L} \\
\mathrm{N}=149 \text { (48.7\%) }\end{array}$ & $\begin{array}{l}\text { Eosinophils } \geq 150 \\
\text { Cells/ } \mu \mathrm{L} \\
\mathrm{N}=157(5 \mathrm{I} .3 \%)\end{array}$ & P-value \\
\hline \multicolumn{5}{|l|}{ Direct health costs due to exacerbations } \\
\hline $\begin{array}{l}\text { Cost of resource use in exacerbations (moderate } \\
\text { and severe) }\end{array}$ & $3273.8(4353.6)$ & $4324.2(5080.2)$ & $2276.9(3243.2)$ & $<0.001$ \\
\hline Cost of resource use in moderate exacerbations & I55.8 (240.9) & I20.8 (|7|.6) & I89.| (288.5) & 0.005 \\
\hline Pharmacological cost & $42.9(152.9)$ & $25.4(37.8)$ & $59.6(209.3)$ & 0.001 \\
\hline Cost of PC visits & $28.2(37.9)$ & $24.3(35.6)$ & $32.0(39.7)$ & 0.060 \\
\hline Cost of SC visits & I $6.7(50.6)$ & $15.7(50.5)$ & $17.7(50.8)$ & 0.811 \\
\hline Cost of emergency visits & $68.0(148.3)$ & $55.4(\mid 38.8)$ & $79.9(156.3)$ & 0.096 \\
\hline Cost of resource use in severe exacerbations & $3117.9(4372.5)$ & $4203.4(5100.6)$ & $2087.7(3240.8)$ & $<0.001$ \\
\hline Pharmacological cost & $526.2(1071.4)$ & $663.6(1131.3)$ & $395.8(997.4)$ & $<0.001$ \\
\hline Cost of hospital admissions & $2491.7(3489.1)$ & $3360.8(4 \mid 89.3)$ & $1667.0(2397.0)$ & $<0.001$ \\
\hline Cost of ICU stay & $99.9(659.9)$ & $179.0(884.7)$ & $24.9(311.5)$ & 0.015 \\
\hline \multicolumn{5}{|l|}{ Fixed health costs in stable phase } \\
\hline Total annual cost of resource use & $2427.5(1377.3)$ & $2378.7(1378.6)$ & $2473.8(1378.8)$ & 0.312 \\
\hline Annual pharmacological cost & $1037.7(627.9)$ & $965.2(489.7)$ & I $106.5(730.5)$ & 0.036 \\
\hline Annual cost of total visits & $336.9(195.6)$ & $321.0(172.4)$ & $352.0(2 \mid 4.8)$ & 0.431 \\
\hline Annual cost of PC visits & $121.2(122.7)$ & $107.9(\mid 15.6)$ & | 33.8 (|28.2) & 0.037 \\
\hline Annual cost of SC visits & $215.8(146.9)$ & $213.1(128.6)$ & $218.3(162.8)$ & 0.492 \\
\hline Annual cost of outpatient tests & $522.9(433.8)$ & $493.9(408.0)$ & $550.3(456.6)$ & 0.153 \\
\hline Annual cost of spirometry & $67.9(37.7)$ & $65.1(36.9)$ & $70.5(38.4)$ & 0.348 \\
\hline Annual cost of blood analyses & $179.6(243.2)$ & $162.3(218.4)$ & $196.0(264.4)$ & 0.030 \\
\hline Annual cost of chest X-ray & $39.9(48.1)$ & $37.3(40.3)$ & $42.3(54.6)$ & 0.809 \\
\hline Annual cost of bronchodilator testing & $46.9(45.1)$ & $40.5(39.8)$ & $52.9(48.9)$ & 0.035 \\
\hline Annual cost of arterial blood gases & $42.0(70.8)$ & $45.0(74.8)$ & $39.1(66.9)$ & 0.188 \\
\hline Annual cost of complete functional testing & $53.7(86.6)$ & $53.0(85.9)$ & $54.3(87.5)$ & 0.889 \\
\hline Annual cost of 6-minute walk test & $15.3(27.3)$ & $13.9(25.2)$ & $16.6(29.1)$ & 0.535 \\
\hline Annual cost of chest $\mathrm{CT}$ & $46.0(97.5)$ & $48.5(104.1)$ & $43.6(91.1)$ & 0.875 \\
\hline Annual cost of $\mathrm{FE}_{\mathrm{NO}}$ measurements & $15.0(44.8)$ & I2.1 (36.6) & $17.8(5 \mid .3)$ & 0.531 \\
\hline Annual cost of other tests & $16.6(6 \mid .1)$ & $16.0(53.4)$ & I7.I (67.7) & 0.885 \\
\hline Annual cost of non-pharmacological treatment & $530.0(1020.0)$ & $598.5(1130.8)$ & $465.0(901.2)$ & 0.544 \\
\hline Annual cost of home oxygen & $289.9(499.4)$ & $310.4(5 \mid 1.5)$ & $270.5(488.4)$ & 0.322 \\
\hline Annual cost vaccinations & $31.3(20.2)$ & $30.7(20.5)$ & $31.9(19.8)$ & 0.611 \\
\hline Annual cost respiratory rehabilitation & $12.7(70.1)$ & $17.8(92.9)$ & $7.75(36.9)$ & 0.550 \\
\hline Annual cost of non-invasive home ventilation & $156.2(680.3)$ & $196.4(756.7)$ & II8.I (598.8) & 0.199 \\
\hline Annual cost of other treatments & $39.8(193.0)$ & $43.1(206.9)$ & $36.73(179.4)$ & 0.899 \\
\hline
\end{tabular}

(Continued) 
Table 3 (Continued).

\begin{tabular}{|c|c|c|c|c|}
\hline Variables & $\begin{array}{l}\text { Total Sample } \\
N=306 \\
(100.0 \%)\end{array}$ & 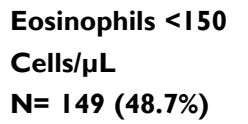 & $\begin{array}{l}\text { Eosinophils } \geq 150 \\
\text { Cells/ } \mu \mathrm{L} \\
\mathrm{N}=157(51.3 \%)\end{array}$ & P-value ${ }^{b}$ \\
\hline \multicolumn{5}{|l|}{ Total cost } \\
\hline Total annual cost & $6720.7(8061.3)$ & $8381.7(9862.5)$ & $5144.4(5443.9)$ & $<0.001$ \\
\hline Total direct health costs (exacerbations + stable phase) & $5701.3(4733.0)$ & $6702.9(5388.4)$ & $4750.7(3792.7)$ & $<0.001$ \\
\hline Total indirect costs & $1019.5(6066.1)$ & $1678.9(7820.5)$ & 393.7 (3620.9) & 0.369 \\
\hline
\end{tabular}

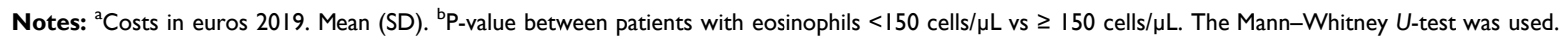

Abbreviations: COPD, chronic obstructive pulmonary disease; PC, primary care; SC, secondary care; ICU, intensive care unit; CT, computed axial tomography; FE $\mathrm{NO}_{\text {, }}$ exhaled nitric oxide test; SD, standard deviation.

The association between high eosinophil levels and the response to corticosteroids, both during exacerbations and in the stable phase of COPD, ${ }^{9,10,12}$ has led to questions about the role of eosinophils in lung diseases. In recent years, interest in blood eosinophil levels in COPD patients as a possible prognostic biomarker has increased. ${ }^{38-40}$ The IMPACT clinical trial, in a population of patients with COPD with similar characteristics to that of our study, showed that the annual rate of moderate or severe exacerbations was lower with triple therapy compared with LABA/LAMA, and a greater reduction in the exacerbation rate was observed in patients with eosinophil levels above 150 cells/ $\mu \mathrm{L} .^{41}$

COPD has a great impact on the quality of life. Our results show a remarkable difference between the mean utility of the study population (0.65 (SD: 0.29)) compared with the mean utility of the Spanish general population (0.91 (SD: 0.18$)),{ }^{42}$ and the mean utility of COPD in general (0.73 (SD: 0.29)). ${ }^{22,43}$

This study had some limitations. Firstly, it was recommended that blood eosinophil levels were collected in the stable phase; however, this was not possible in all patients. Quantifying blood eosinophils during an exacerbation may result in lower values due to the use of systemic corticosteroids. Secondly, the setting selected and the retrospective design of the study may underestimate the economic impact of exacerbating COPD, since visits to other hospitals or specialists were not collected, as well as we did not consider non-healthcare direct costs relevant to COPD, such as formal and informal cares. These costs may amount up to $38 \%$ of the total cost of COPD. ${ }^{4,44}$ In addition, the indirect costs included only those associated with lost workdays attributable to COPD. Finally, 305 patients in our study were treated with open-triple therapy. Currently, there are devices on the market that allow single-inhaler triple therapy, which might reduce the real cost by improving adherence and outcomes. ${ }^{45}$ This study might not be representative of the management in other Spanish hospitals. Therefore, generalization of the results may be limited and should be interpreted with caution. In summary, the high economic impact of COPD and its
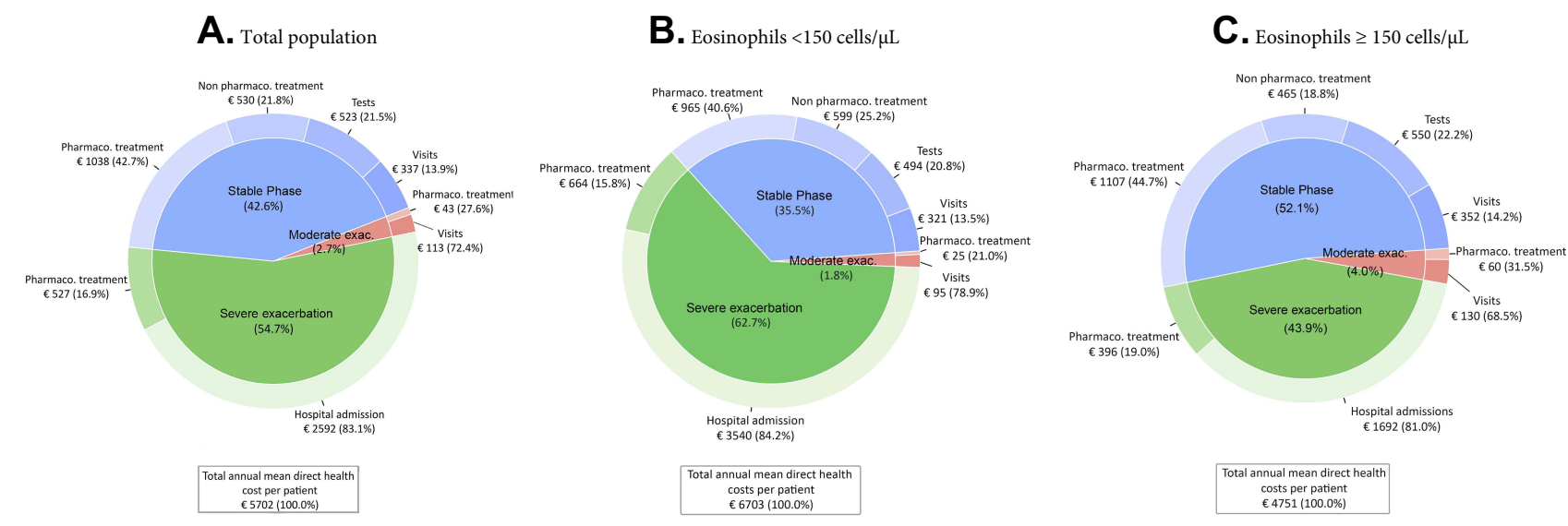

Figure 3 Distribution of total direct health costs per COPD patient in the last 12 months. 
exacerbations in Spain is evident. In addition, we found that patients may not achieve optimal disease control despite medication. The results of this study suggest that further studies of new targeted therapies and new biomarkers are needed to guide and improve treatment. Additionally, studies that include a cost-effectiveness analysis may be beneficial, given the high cost of these therapies, to support their use when appropriate. ${ }^{46}$

\section{Acknowledgments}

The authors acknowledge the participation of Alonso Viteri, S (H. Torrejón de Ardoz); Baloira Villar, A (H. U. Pontevedra); Bollo de Miguel, E (Complejo Asistencial Universitario de León); Bonnin Vilaplana, M (H. Figueres y HU Dr. Josep Trueta); Bravo Blanco, D (HU. Araba); Coloma Bazán, E (H. Clínic Barcelona); Galera, R (H.U. La Paz); García Rivero, JL (H. Comarcal de Laredo); García-Sidro, P (HU. de la Plana); Gómez Neira, MC (H. Lucus Augusti de Lugo); Herrejón, A (H. U. Dr. Peset); Huerta García, A (H. Clínico de Barcelona); Malo de Molina Ruiz, R (HU. Puerta de Hierro de Majadahonda); Martínez González, C (HUCA); Martinez Rivera, C (H. Germans Trias i Pujol); Nuñez A, (HU. Vall d' Hebron); Montón Soler, C (H. Sabadell); Gotera, C (Fundación Jiménez Díaz); Rodríguez Pons, L (H. Germans Trias y Pujol); Sánchez Lora, FJ (H. Virgen de la Victoria); Velasco Garrido, JL (H. Clínico Málaga) for patient recruitment and data collection and Huerta A for the conception of the analysis.

\section{Funding}

This study was funded by GlaxoSmithKline (study 206555).

\section{Disclosure}

Bernardino Alcázar-Navarrete reports grants and personal fees from GSK, grants, personal fees and non-financial support from Novartis AG, personal fees and non-financial support from Boehringer Ingelheim, personal fees and non-financial support from Chiesi, Laboratories FAES, and Gilead, grants, personal fees and non-financial support from Laboratorios Menarini, personal fees from Gebro, personal fees from Astra- Zeneca, personal fees from Laboratorios Rovi, personal fees from Laboratorios Ferrer. Francisco García-Rio has received speaker fees from Boehringer Ingelheim, Pfizer, Chiesi, GlaxoSmithKline, Menarini, Novartis and Rovi, and consulting fees from Boehringer Ingelheim, Pfizer,
GlaxoSmithKline and Novartis. Guadalupe Sánchez and Andrea García, are GSK employees. Esther Mariscal was a GSK employee when the study was conducted. Maribel Cuesta and Estefany Uría, are employees of Oblikue Consulting and were involved in data monitoring board, study design, manuscript preparation, and statistical analysis for GlaxoSmithKline. Marc Miravitlles has received speaker fees from AstraZeneca, Boehringer Ingelheim, Chiesi, Cipla, Menarini, Rovi, Bial, Sandoz, Zambon, CSL Behring, Grifols and Novartis, consulting fees from AstraZeneca, Boehringer Ingelheim, Chiesi, GlaxoSmithKline, Bial, Gebro Pharma, Kamada, CSL Behring, Laboratorios Esteve, Ferrer, Mereo Biopharma, Verona Pharma, TEVA, Spin Therapeutics, pH Pharma, Novartis, Sanofi and Grifols and research grants from and Grifols. The authors report no other conflicts of interest in this work.

\section{References}

1. Global Initiative for Chronic Obstructive Lung Disease. Global Strategy for the Diagnosis, Management, and Prevention of Chronic Obstructive Pulmonary Disease (2020 Report). Available from: https://goldcopd.org/gold-reports/. Accessed April 1, 2019.

2. Soriano JB, Alfageme I, Miravitlles M, et al. Prevalence and determinants of COPD in Spain: EPISCAN II. Arch Bronconeumol. 2021;57(1):61-69.

3. Masa JF, Sobradillo V, Villasante C, et al. Costs of chronic obstructive pulmonary disease in Spain. Estimation from a population-based study. Arch Bronconeumol. 2004;40(2):72-79.

4. Merino M, Villoro R, Hidalgo-Vega Á, Carmona C. Social economic costs of COPD in Extremadura (Spain): an observational study. Int J Chron Obstruct Pulmon Dis. 2018; Volume 13:2501-2514.

5. Pérez M, Puig-Peiró R, Paz S, Lizán L. Coste directo de la enfermedad pulmonar obstructiva crónica asociado a variaciones en adherencia y persistencia. Rev Patol Respir. 2015;18(2):49-56.

6. Miravitlles M, Ribera A. Understanding the impact of symptoms on the burden of COPD. Respir Res. 2017;18(1):67.

7. Calle Rubio M, Rodríguez Hermosa JL, Soler-Cataluña JJ, et al. Medical Care According To Risk Level And Adaptation to Spanish COPD Guidelines (Gesepoc): the Epoconsul study. Arch Bronconeumol. 2018;54(5):270-279.

8. Zhang Y, Morgan RL, Alonso-Coello P, et al. A systematic review of how patients value COPD outcomes. Eur Respir J. 2018;52(1):1.

9. Pascoe S, Locantore N, Dransfield MT, Barnes NC, Pavord ID. Blood eosinophil counts, exacerbations, and response to the addition of inhaled fluticasone furoate to vilanterol in patients with chronic obstructive pulmonary disease: a secondary analysis of data from two parallel randomised controlled trials. Lancet Respir Med. 2015;3(6):435-442.

10. Siddiqui SH, Guasconi A, Vestbo J, et al. Blood eosinophils: a biomarker of response to extrafine beclomethasone/formoterol in chronic obstructive pulmonary disease. Am J Respir Crit Care Med. 2015;192(4):523-525. 10.1164/rccm.201502-0235LE

11. Bafadhel M, McCormick M, Saha S, et al. Profiling of sputum inflammatory mediators in asthma and chronic obstructive pulmonary disease. Respiration. 2012;83(1):36-44. 10.1159/000330667

12. Bafadhel M, Davies L, Calverley PMA, Aaron SD, Brightling CE, Pavord ID. Blood eosinophil guided prednisolone therapy for exacerbations of COPD: a further analysis. Eur Respir J. 2014;44 (3):789-791. 
13. Vedel-Krogh S, Nielsen SF, Lange P, Vestbo J, Nordestgaard BG. Blood eosinophils and exacerbations in Chronic Obstructive Pulmonary Disease. The copenhagen general population study. Am J Respir Crit Care Med. 2016;193(9):965-974.

14. Miravitlles M, Monteagudo M, Solntseva I, Alcázar B. Blood eosinophil counts and their variability and risk of exacerbations in COPD: a population-based study. Arch Bronconeumol. 2021;57(1):13-20.

15. Golpe R, Dacal D, Sanjuán-López P, Martín-Robles I, Pérez-de-llano LA. Plasma eosinophil count and patient-centered events in chronic obstructive pulmonary disease in real-life clinical practice. Arch Bronconeumol. 2020;56(2):129-130.

16. Miravitlles M, Murio C, Guerrero T, Gisbert R. Costs of chronic bronchitis and COPD: a 1-year follow-up study. Chest. 2003;123 (3):784-791.

17. de Miguel Diez J, Carrasco Garrido P, García Carballo M, et al. Determinants and predictors of the cost of COPD in primary care: a Spanish perspective. Int J Chron Obstruct Pulmon Dis. 2008;3 (4):701-712.

18. International Conference of Harmonization (ICH). ICH Tripartite Guideline for Good Clinical Practices E6 (R1).

19. International Epidemiological Association-European Epidemiology Federation. Good epidemiological practice (GEP) IEA guidelines for proper conduct in epidemiologic research. 2007. Available from: http://ieaweb.org/good-epidemiological-practice-gep/.

20. Rieger-Reyes C, García-Tirado FJ, Rubio-Galán FJ, Marín-Trigo JM. Clasificación de la gravedad de la enfermedad pulmonar obstructiva crónica según la nueva guía Iniciativa Global para la Enfermedad Obstructiva Crónica 2011: COPD Assessment Test versus modified Medical Research Council. Arch Bronconeumol. 2014;50(4):129-134.

21. Jones PW, Harding G, Berry P, Wiklund I, Chen W-H, Kline Leidy N. Development and first validation of the COPD Assessment Test. Eur Respir J. 2009;34(3):648-654.

22. Esquinas C, Ramon MA, Nuñez A, et al. Correlation between disease severity factors and EQ-5D utilities in chronic obstructive pulmonary disease. Qual Life Res. 2020;29(3):607-617.

23. Ramos-Goñi JM, Pinto-Prades JL, Oppe M, Cabasés JM, Serrano-Aguilar P, Rivero-Arias O. Valuation and modeling of EQ-5D-5L health states using a hybrid approach. Med Care. 2017;55(7):e51-e58.

24. Gisbert R, Brosa M. Healthcare Cost Database eSALUD. Oblikue Consulting, SL; 2019. Available from:http://www.oblikue.com/en/ index.htm. Accessed April 1, 2019.

25. Consejo General de Colegios Oficiales de Farmacéuticos. Bot PLUS 2.0. 2013. Available from: https://botplusweb.portalfarma.com. Accessed April 1, 2019.

26. Del Estado. J [Spanish Royal Decree-Law 8/2010, May 20, whereby extraordinary measures are adopted to reduce the public deficit]. Boletín Oficial del Estado. 2010. Available from: https://www.boe.es/diario_boe/ txt.php?id=BOE-A-2010-8228. Accessed August 17, 2017.

27. Instituto Nacional de Estadística [INE]. [Annual Survey of Salary Structure 2016]. 2019. Available from: http://www.ine.es/. Accessed April 1, 2019.

28. Soriano JB, Miravitlles M, Borderías L, et al. Geographical variations in the prevalence of COPD in Spain: relationship to smoking, death rates and other determining factors. Arch Bronconeumol. 2010;46 (10):522-530.

29. Watz H, Tetzlaff K, Wouters EFM, et al. Blood eosinophil count and exacerbations in severe chronic obstructive pulmonary disease after withdrawal of inhaled corticosteroids: a post-hoc analysis of the WISDOM trial. Lancet Respir Med. 2016;4(5):390-398.
30. Müllerová H, Meeraus WH, Galkin DV, Albers FC, Landis SH. Clinical burden of illness among patients with severe eosinophilic COPD. Int J Chron Obstruct Pulmon Dis. 2019;14:741-755.

31. Miravitlles M, Calle M, Molina J, et al. Spanish COPD Guidelines (GesEPOC) 2021: updated Pharmacological treatment of stable COPD. Arch Bronconeumol. 2021; Mar 17:S0300-2896(21)00103-4. Online ahead of print.

32. Medina Gallardo J, Álvarez Guitiérrez F, Bordoy Sánchez M, et al. Análisis de los costes directos durante un año de pacientes con EPOC seguidos en una consulta neumológica extrahospitalaria. Neumosur. 2005;17(4):232-237.

33. Trudo F, Kallenbach L, Vasey J, et al. Clinical and economic burden of eosinophilic COPD in a large retrospective US cohort. Int J Chron Obstruct Pulmon Dis. 2019;14:2625-2637.

34. López-Campos JL, Carrasco-Hernández L, Román Rodríguez L, Quintana-Gallego E, Carmona Bernal C, Alcázar Navarrete B. The clinical implications of triple therapy in fixed-dose combination in COPD: from the trial to the patient. Arch Bronconeumol. 2020;56 (4):242-248.

35. Benson VS, Pascoe KC, Siddall J, Small M, Müllerová H. Exacerbation frequency and eosinophil counts among patients with COPD currently prescribed triple therapy. Int J COPD. 2019;14: 2711-2723.

36. Calverley PMA, Magnussen H, Miravitlles M, Wedzicha JA. Triple Therapy in COPD: what we know and what we don't. COPD J Chronic Obstr Pulm Dis. 2017;14(6):648-662.

37. Soler-Cataluña JJ, Alcázar B, Miravitlles M. Clinical Control in COPD: a new therapeutic objective? Arch Bronconeumol. 2020;56 (2):68-69.

38. Pérez de Llano L, Cosío BG, Miravitlles M, Plaza V; CHACOS study group. Accuracy of a New Algorithm to Identify Asthma-COPD Overlap (ACO) patients in a cohort of patients with Chronic Obstructive Airway Disease. Arch Bronconeumol. 2018;54 (4):198-204.

39. Brusselle G, Pavord ID, Landis S, et al. Blood eosinophil levels as a biomarker in COPD. Respir Med. 2018;138:21-31.

40. Gonzalez-Barcala F, San-Jose M, Nieto-Fontarigo J, et al. Blood eosinophils could be useful as a biomarker in chronic obstructive pulmonary disease exacerbations. Int J Clin Pract. 2019;73:12.

41. Lipson DA, Barnhart F, Brealey N, et al. Once-daily single-inhaler triple versus dual therapy in patients with COPD. $N$ Engl J Med. 2018;378(18):1671-1680.

42. Instituto Nacional de Estadística [INE]. Encuesta Nacional de Salud 2011; 2019. Available from: www.ine.es.

43. Miravitlles M, Huerta A, Valle M, et al. Clinical variables impacting on the estimation of utilities in chronic obstructive pulmonary disease. Int J Chron Obstruct Pulmon Dis. 2015;10:367-377.

44. Miravitlles M, Peña-Longobardo LM, Oliva-Moreno J, HidalgoVega Á. Caregivers' burden in patients with COPD. Int $J$ Chron Obstruct Pulmon Dis. 2015;10:347-356.

45. Miravitlles M, Marín A, Huerta A, Carcedo D, Villacampa A, PuigJunoy J. Estimation of the clinical and economic impact of an improvement in adherence based on the use of once-daily single-inhaler triple therapy in patients with COPD. Int $J$ Chron Obstruct Pulmon Dis. 2020;15:1643-1654.

46. Donovan T, Milan SJ, Wang R, Banchoff E, Bradley P, Crossingham I. Anti-IL-5 therapies for chronic obstructive pulmonary disease. Cochrane Database Syst Rev. 2020;12:CD013432. 


\section{Publish your work in this journal}

The International Journal of COPD is an international, peer-reviewed journal of therapeutics and pharmacology focusing on concise rapid reporting of clinical studies and reviews in COPD. Special focus is given to the pathophysiological processes underlying the disease, intervention programs, patient focused education, and self management

protocols. This journal is indexed on PubMed Central, MedLine and CAS. The manuscript management system is completely online and includes a very quick and fair peer-review system, which is all easy to use. Visit http://www.dovepress.com/testimonials.php to read real quotes from published authors. 